\title{
On Essentiality of RoHS in EE R\&D Ecosystem
}

\author{
S D Das and S Chatterjee \\ $R \& D$ Electronics, Ministry of Electronics and Information Technology, India
}

\begin{abstract}
Sustainable development demands environmentally friendly products and hence Research and Development ecosystem needs to adopt environmental compliances. This fact is truer for Electrical and Electronics products as its new product launch rate is very high which also produces high rate of obsolescence and hence e-waste. In India one of the environmental standards is RoHS and in this review a case has been presented for early adoption of the compliance in Indian Research and Development ecosystem through modified Nair's Product Development Cycle. Advantages of early adoption are avoidance of repetition of expected pollution from e-waste again in future, preventing health issues among researchers who handle such substances and improvement of industry confidence on the pre-competitive $R \& D$. Finally RoHS2 instead of RoHS1 has been recommended for adoption to prevent rejection of developed product in future.
\end{abstract}

Keywords: RoHS, R\&D, WEEE, E-waste, sustainability

\section{Introduction}

Sustainable development of a country in globalization scenario has made it necessary to be competitive and knowledge economy as key for its success. These are achievable through innovation. Innovation in this case can be defined as generation of new ideas that would translate into value added products and services which could intern provide sustainable development [1]. Sustainable development is social development which fulfills the needs of present generation without endangering the possibilities of fulfillment of the needs of future generation [2]. From this definition a technology should be sustainable when it is economically viable, socially acceptable and ecologically viable for long run [3]. Hence when a product is developed it has to be innovative to beat competition and also provide sustainability in long run. For Electrical and Electronics equipment this fact is more true than for other sectors of manufacturing, as the pace of new product launch is exceptionally high which creates high rate of obsolescence and electronic waste (e-waste). E-waste is end of life Electrical and Electronic Equipment (EEE) and its components. Disposal of e-waste is a major issue as without proper disposal or recycling could create pollution and health hazards. There exist two solutions for e-waste problem; one recycling in environmental friendly manner and two creating environmental friendly products. In this paper only development of environmental friendly products will be discussed. India has initiated a big push to manufacture electrical and electronic (EE) products and hence new innovative products will be part of the ecosystem delivery. But to ensure this growth is sustainable, Research and Development (R\&D) ecosystem needs to adopt sustainable goals, i.e, EE products when becomes e-waste they should be easily recyclable and does not cause environmental pollution during any stage of product life (research, manufacturing, during use, refurbishing, e-waste dump and e-waste recycling). In India, e-waste is managed under E-waste Rules enacted by Ministry of Environment \& Forest and Climate Change (MoEF\&CC), Government of India and Reduction in use of Hazardous Substances (RoHS) is part of this rule which provides restrictions or maximum limits of environmentally hazardous substances in EE products.

In this paper, detailed discussion will be presented on e-waste issues particularly the harms it produces and need of adoption of RoHS in Indian R\&D ecosystem, RoHS at national and international level followed by how RoHS could be included in R\&D product development cycle. Indian R\&D ecosystem's awareness on this compliance issue is very short and this paper is expected to enrich the community with the RoHS rules, its background and future. This review provides a view to support early adoption of RoHS in Indian R\&D ecosystem through modified Nair's Product Development Cycle.

\section{Harms of e-waste}

Like other parts of the world, India is also facing serious challenges due to growing generation of e-waste and its lack of awareness among public, consumers, producers and other stake holders. The Central Pollution Control Board (CPCB), Government of India had carried out a survey during 2005, which estimated the e-waste generation of approximately 0.8 million MT during 2012. An assessment, carried out by United Nation University in 2014 predicted India has generated 1.7Mn MT of e-waste in 2014 [4]. Another study, carried out by Assocham in June 2016, showed the generation of e-waste would reach 52 lakh MT per annum by 2020 in India from the current level of 18 lakh MT, growing at a compound annual growth rate (CAGR) of about 30\% [5]. This along with historic e-waste contains harmful or hazardous substances which can pollute air, 
Table I. Health Hazards of restricted substance by RoHS.

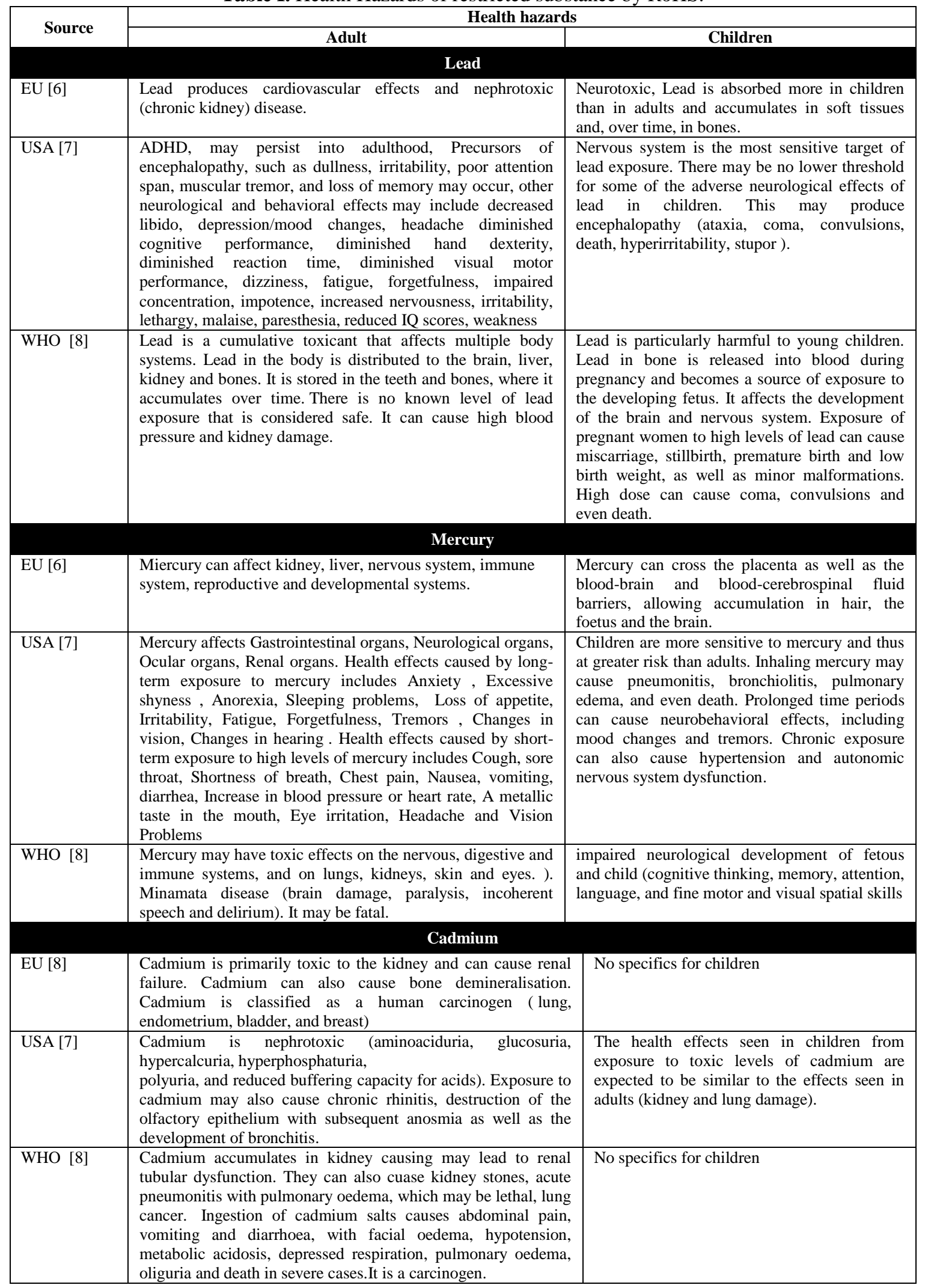


On Essentiality of RoHS in EE R\&D Ecosystem

\begin{tabular}{|c|c|c|}
\hline \multirow{2}{*}{ Source } & \multicolumn{2}{|l|}{ Health hazards } \\
\hline & Adult & Children \\
\hline \multicolumn{3}{|c|}{ Hexavalent Chromium } \\
\hline EU [6] & $\begin{array}{l}\text { Chromium VI causes rashes and ulcers, reduced sperm count } \\
\text { and semen quality, DNA damage, cancer. }\end{array}$ & $\begin{array}{l}\text { Children are assessed to be vulnerable } \\
\text { subgroup }\end{array}$ \\
\hline USA [7] & $\begin{array}{l}\text { Hex. Chromium effects include irritation of the lining of the } \\
\text { nose, runny nose, and breathing problems (asthma, cough, } \\
\text { shortness of breath, wheezing). Stomach and small intestine } \\
\text { problems (irritation and ulcer), blood (anemia), sperm damage } \\
\text { and damage to the male reproductive system in animals } \\
\text { observed. Chromium compounds are carcinogenic to humans. }\end{array}$ & $\begin{array}{l}\text { Children would have the same health effects } \\
\text { as adults. }\end{array}$ \\
\hline WHO [8] & $\begin{array}{l}\text { Hex. Chromium can cause lung cancer and is expected to be } \\
\text { genotoxic. }\end{array}$ & No specifics for children \\
\hline \multicolumn{3}{|c|}{ Polybrominated biphenyls (PBB) } \\
\hline USA [7] & $\begin{array}{l}\text { Studies on humans in conclusive. Laboratory animals fed PBBs } \\
\text { had body weight loss, skin disorders, and nervous system } \\
\text { effects, and their livers, kidneys, thyroid glands, and immune } \\
\text { systems were seriously injured. Some animals fed high amounts } \\
\text { died. PBBs also caused birth defects in animals. }\end{array}$ & $\begin{array}{l}\text { Animal studies found that exposure to PBBs } \\
\text { during pregnancy or lactation caused changes } \\
\text { in thyroid hormone levels in the newborn } \\
\text { animals and, at high doses, increases in } \\
\text { prenatal death and structural birth defects. } \\
\text { PBBs are stored in the mother's body and can } \\
\text { be released during pregnancy, cross the } \\
\text { placenta, and enter fetal tissues. Because PBBs } \\
\text { dissolve readily in fat, they can accumulate in } \\
\text { breast milk fat and be transferred to babies and } \\
\text { young children. }\end{array}$ \\
\hline USA [7] & $\begin{array}{l}\text { There is no definite information on health effects of PBDEs in } \\
\text { people. Rats and mice that ate food with moderate amounts of } \\
\text { PBDEs for a few days had effects on the thyroid gland. Those } \\
\text { that ate smaller amounts for weeks or months had effects on the } \\
\text { thyroid and the liver. Large differences in effects are seen } \\
\text { between highly-brominated and less-brominated PBDEs in } \\
\text { animal studies. } \\
\text { Preliminary evidence suggests that high concentrations of } \\
\text { PBDEs may cause neurobehavioral alterations and affect the } \\
\text { immune system in animals. }\end{array}$ & $\begin{array}{l}\text { Children are exposed to PBDEs in generally } \\
\text { the same way as adults, mainly by eating } \\
\text { contaminated food. Because PBDEs dissolve } \\
\text { readily in fat, they can accumulate in breast } \\
\text { milk and may be transferred to babies and } \\
\text { young children. Exposure to PBDEs in the } \\
\text { womb and through nursing has caused thyroid } \\
\text { effects and neurobehavioral alterations in } \\
\text { newborn animals. }\end{array}$ \\
\hline WHO [8] & $\begin{array}{l}\text { Associated with cryptorchidism in males. Causes decrease in } \\
\text { thyroid hormones in animals }\end{array}$ & No specifics for children \\
\hline
\end{tabular}

Water \& land; and eventually enter human body. As discussed in previous section a list of hazardous substances is maintained through the E-waste Rules under RoHS guidelines by Government of India. Health hazards of restricted substances in RoHS substances are listed in Table I., which shows that these substances cause severe health problems to death to humans. In some cases children are more vulnerable than adults. The data presented in Table I should not be taken as compulsory effect to human body as toxicity to humans depends on how it has entered human body, quantity of consumption and duration of consumption. Also data presented shows variation among different organizations. Never the less any harm that a substance could cause to a human and especially to children needs to be restricted in all sense. These chemicals also cause harm to wild life. The hazardous chemicals leak into environment during manufacturing, during product use and after end of life during waste stage and recycling stage. As on October 2015, there are 149 registered e-waste dismantlers/ recyclers in India with a total e-waste dismantling \& recycling capacity of 4.61 lakhs MT per annum [10], a mere $8.9 \%$ of expected e-waste tonnage by 2020 . Hence, most of the e-waste is expected to be either become landfill or recycled by informal sector. Informal sector uses unscientific and non-environmental friendly recycling techniques which causes severe pollution. In this context, contribution from $R \& D$ ecosystem especially from researchers is of paramount importance. They have the social and moral responsibility to avoid the use of such hazardous materials in future EE products which are currently under development. Moreover, researchers who deal with such hazardous materials could themselves develop health issues if proper 
precautions are not taken. This creates the necessity for the R\&D community to understand RoHS rules and its applicability in R\&D.

\section{RoHS}

RoHS regulations in India are provided under E-waste Rules. MoEF\&CC has enacted two versions of E-waste Rules; one in 2011 and the other in 2016. They are known as E-waste (Management \& Handling) Rules 2011 and E-waste (Management) Rules 2016, respectively. E-waste (Management) Rules 2016 has come into force from 1st October 2016 in suppression of E-waste (Management \& Handling) Rules 2011 [11]. Both versions have kept provisions of REDUCTION IN THE USE OF HAZARDOUS SUBSTANCES (RoHS) in chapter $\mathrm{V}$ of the rules. A comparative chart of the RoHS provisions has been provided in Table II.

RoHS has been initiated under European Union (EU) which has now been adopted by many countries other than India like China, Japan, South Korea, Turkey, California (USA), Ireland and Sweden; in different forms and under different names. European Union (EU) treats Waste of electrical and electronic equipment (WEEE) and hazardous substance legislations differently while these two rules are under same enactment in India. In this paper, only hazardous substance rule has been compared. Current EU RoHS directive is Directive 2011/65/EU (or RoHS2) which was last amended with Commission Delegated Directive (EU) 2016/585, of $12^{\text {th }}$ February 2016 [12]. A comparison chart for restricted substances in current EU RoHS directive and Indian RoHS Rules 2016 is provided in Table III. In EU directives, four extra substances are present namely DEHP,

Table II. RoHS provisions in E-waste rules: 2011 \& 2016

\begin{tabular}{|c|c|}
\hline $\begin{array}{l}\text { E-waste (Management \& Handling) } \\
\text { Rules } 2011\end{array}$ & $\begin{array}{l}\text { E-waste (Management) } \\
\text { Rules } 2016\end{array}$ \\
\hline $\begin{array}{l}\text { Applicability was limited to Manufacturing of Electrical and } \\
\text { Electronics Equipment }\end{array}$ & $\begin{array}{l}\text { Applicability has been enhanced to Manufacturing of } \\
\text { Electrical and Electronics Equipment and their CCPS }\end{array}$ \\
\hline Scope included Schedule I listed equipments only & $\begin{array}{l}\text { Scope includes equipments and their CCPS }{ }^{\mathrm{a}} \text { for items listed in } \\
\text { Schedule I. Fluorescent and other mercury containing lamps } \\
\text { have been added to Schedule I of } 2011 \text { Rules. }\end{array}$ \\
\hline $\begin{array}{l}\text { Restricted Substance list with maximum limit } \\
\text { Lead }-1000 \mathrm{ppm} \\
\text { Mercury }-1000 \mathrm{ppm} \\
\text { Cadmium }-100 \mathrm{ppm} \\
\text { Hex. Chromium }-1000 \mathrm{ppm} \\
\text { PBB }^{\mathrm{c}}-1000 \mathrm{ppm} \\
\text { PBDE }^{\mathrm{d}}-1000 \mathrm{ppm} \\
\end{array}$ & $\begin{array}{l}\text { Restricted Substance list with maximum limit } \\
\text { Lead }-1000 \mathrm{ppm} \\
\text { Mercury }-1000 \mathrm{ppm} \\
\text { Cadmium }-100 \mathrm{ppm} \\
\text { Hex. Chromium }-1000 \mathrm{ppm} \\
\text { PBB }^{\mathrm{c}}-1000 \mathrm{ppm} \\
\text { PBDE }^{\mathrm{d}}-1000 \mathrm{ppm} \\
\end{array}$ \\
\hline $\begin{array}{l}\text { Exemption List: } \\
\text { Schedule II comprises of list of equipments which are } \\
\text { exempted from RoHS regulations. Also, defense and strategic } \\
\text { equipments are exempted from RoHS regulations. }\end{array}$ & $\begin{array}{l}\text { Exemption List: } \\
\text { Schedule II list has not been changed in terms of content but } \\
\text { specifications of } 5 \text { items have been changed. Exemption for } \\
\text { defense and strategic equipments remains }\end{array}$ \\
\hline $\begin{array}{l}\text { Exemption date } \\
\text { The Rule was applicable to components of equipments } \\
\text { manufactured or placed in the market from } 2005 .\end{array}$ & $\begin{array}{l}\text { Exemption date } \\
\text { CCPS for equipment placed in the market before 1st May } \\
\text { 2014, provided RoHS compliant parts and spares are not } \\
\text { available }\end{array}$ \\
\hline $\begin{array}{l}\text { Product Information Booklet: } \\
\text { Must include information regarding constituents }\end{array}$ & $\begin{array}{l}\text { Product User Documentation: } \\
\text { Must include: } \\
\text { a) Declaration of conformance } \\
\text { b) constituents of equipment \& their CCPS }\end{array}$ \\
\hline$\frac{\text { New Products }}{\text { Allowed only if RoHS compliant }}$ & $\frac{\text { New Products }}{\text { No change is this provision }}$ \\
\hline No such provisions & $\begin{array}{l}\text { EPR Authorization } \\
\text { Producer has to self-declare compliance of RoHS provisions }\end{array}$ \\
\hline No such provisions & $\begin{array}{l}\text { Enforcement \& Penalties: } \\
\text { a) CPCB will take samples of any product from market and } \\
\text { verify RoHS compliance } \\
\text { b) In absence of RoHS compliance product could be } \\
\text { withdrawn or recalled from market until compliance is } \\
\text { assured by company }\end{array}$ \\
\hline & $\begin{array}{r}{ }^{\mathrm{a}} \text { Components or consumables or parts or spares } \\
{ }^{\mathrm{b}} \text {. for homogenous samples } \\
{ }^{c} \text { Polybrominated biphenyls } \\
\text { d.Polybrominated diphenyls ethers }\end{array}$ \\
\hline
\end{tabular}

BBP, DBP and DIBP (full forms in Table III). The restriction of these four substances only apply to medical devices, including in vitro medical devices, and monitoring and control instruments, including industrial monitoring and control instruments, from 22 July 2021 and does not apply to cables or spare parts for repair, reuse, updating of functionalities or upgrading of capacity of EEE placed on the market before 22 July 2019, and of medical devices, including in vitro medical devices, and monitoring and control instruments, including 
industrial monitoring and control instruments, placed on market before 22 July 2021. These restrictions also do not apply to toys which are already under such restrictions from other EU regulations.

Table III. Comparison of EU RoHS directive (EU) 2016/585 and indian RoHS provisions 2016

\begin{tabular}{|c|c|}
\hline Indian RoHS provisions 2016 & EU RoHS directive (EU) 2015/863 \\
\hline $\begin{array}{l}\text { Restricted Substance list with maximum limits } \\
\text { 1. Lead }-0.1 \% \\
\text { 2. Mercury }-0.1 \% \\
\text { 3. Cadmium }-0.01 \% \\
\text { 4. Hex. Chromium }-0.1 \% \\
\text { 5. } \text { PBB }^{\mathrm{b}}-0.1 \% \\
\text { 6. } \text { PBDE }^{\mathrm{c}}-0.1 \%\end{array}$ & $\begin{array}{l}\text { Restricted Substance list with maximum limits } \\
\text { 1. Lead }-0.1 \% \\
\text { 2. Mercury }-0.1 \% \\
\text { 3. Cadmium }-0.01 \% \\
\text { 4. Hex. Chromium - } 0.1 \% \\
\text { 5. } \text { PBB }^{\mathrm{b}}-0.1 \% \\
\text { 6. } \mathrm{PBDE}^{\mathrm{c}}-0.1 \% \\
\text { 7. } \mathrm{DEHP}^{\mathrm{d}}-0.1 \% \\
\text { 8. } \mathrm{BBP}^{\mathrm{e}}-0.1 \% \\
\text { 9. } \mathrm{DBP}^{\mathrm{f}}-0.1 \% \\
\text { 10. } \mathrm{DIBP}^{\mathrm{g}}-0.1 \%\end{array}$ \\
\hline $\begin{array}{l}\text { Scope of application: } \\
\text { 1. Information technology and telecommunication } \\
\text { equipment: } \\
\text { Mainframes, Minicomputers, Personal Computers (CPU } \\
\text { with input and output devices), Laptop (Central } \\
\text { Processing Unit with input and output devices), Notebook, } \\
\text { Notepad, Printers including cartridges Copying } \\
\text { equipment, Electrical and electronic typewriters, User } \\
\text { terminals and systems, Facsimile, Telex, Telephones, Pay } \\
\text { telephones, Cordless telephones, Cellular telephones, } \\
\text { Answering systems } \\
\text { 2. Consumer electrical and electronics } \\
\text { Television sets (including sets based on LCD and LED), } \\
\text { Refrigerator, Washing Machine, Air-conditioners } \\
\text { (excluding centralised air conditioning plants), } \\
\text { Fluorescent and other Mercury containing lamps }\end{array}$ & $\begin{array}{l}\text { Scope of application: } \\
\text { 1. Large household appliances. } \\
\text { 2. Small household appliances. } \\
\text { 3. IT and telecommunications equipment. } \\
\text { 4. Consumer equipment. } \\
\text { 5. Lighting equipment. } \\
\text { 6. Electrical and electronic tools. } \\
\text { 7. Toys, leisure and sports equipment. } \\
\text { 8. Medical devices. } \\
\text { 9. Monitoring and control instruments including } \\
\text { industrial monitoring and control instruments. } \\
\text { 10. Automatic dispensers. } \\
\text { 11. Other EEE not covered by any of the categories } \\
\text { above. }\end{array}$ \\
\hline & $\begin{array}{r}{ }^{\mathrm{a}} \text {. for homogenous samples } \\
{ }^{\mathrm{b}} \text { Polybrominated biphenyls } \\
{ }^{\mathrm{c}} \text { Polybrominated diphenyls ethers } \\
{ }^{\mathrm{d}} \text { Bis(2-ethylhexyl) phthalate } \\
{ }^{\mathrm{e}} \text {. Butyl benzyl phthalate } \\
{ }_{\mathrm{f}}^{\mathrm{f}} \text {. Dibutyl phthalate } \\
{ }^{\mathrm{g}} \text {. Diisobutyl phthalate }\end{array}$ \\
\hline
\end{tabular}

Indian RoHS provisions only applies to producers of electrical and electronic equipment (EEE) and their components or consumables or parts or spares manufacturers whereas EU directive applies to manufacturers, importers, authorized representatives, distributers, and economic operators of EEE equipment. Scope of application of these rules is provided in Table III. It is clear that Indian provisions have two categories of EE equipment: a) Information technology and telecommunication equipment, and b) Consumer electrical and electronics; whereas EU directive divides its EE equipment in 11 categories. Scope of EU directive is much wider with $11^{\text {th }}$ category accounting for all other EEE not covered by any of the categories between 1 and 10. No such

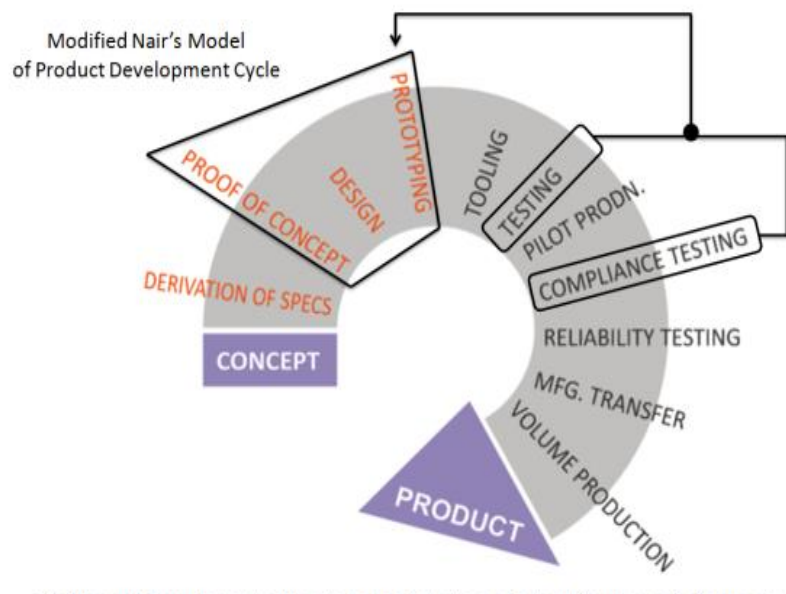

Testing and Compliance testing steps needs to be carried out from proof of concept to prototyping stages to increase confidence of industry

Fig. 1 Modified Nair's Product Development Cycle 
provisions have been made in Indian RoHS provisions in Schedule I, making its scope much limited. EU enforcement of the directives is through national enforcement bodies, for example for UK National Measurement Office and for France it is Ministry for Ecology and Sustainable Development while Indian provisions are enforced by Central Pollution Control Board (CPCB) under MoEF\&CC. Penalties in EU directives involves fines and costs, plus imprisonment in some EU states. In India penalty is withdrawal or recall of products from market till producers take corrective measures to bring the product into compliance within a reasonable period as per the guidelines of the CPCB. EU directive provides a procedure for RoHS exemption requests that includes defined criteria, which can be used for justification, and time limitations. Indian provisions however, do not provide such procedure and exemption is based on Schedule II and defense \& strategic criteria.

\section{RoHS and R\&D}

For R\&D, Table II, row three on maximum limits that are set for restricted substances is the most important part and how it is applied. Products are RoHS compliant or not depend on definition of the term "homogenous material". According to RoHS 2016, the limits for RoHS are set for homogenous materials in the product. Although definition for the term has not being provided in the RoHS rule 2016 itself but it means that the limits do not apply to the weight of the finished product, or even to a component, but to any single substance that could be mechanically disjointed or separated into different materials. For example, the total concentration of cadmium by weight in a product like wire cable may only be $100 \mathrm{ppm}$. Since the limit is $1000 \mathrm{ppm}$, this cable initially appears to be RoHS compliant. However, the concentration in one of the mechanically disjoined element like metal conductor or jacket or in any other element of the cable may be $4000 \mathrm{ppm}$, well above the $1000 \mathrm{ppm}$ limit specified by RoHS. Therefore, this cable would not be RoHS compliant under the E-waste (Management) Rules 2016. Various different technologies are used for manufacturing of different elements of cables. Some of these technologies do use RoHS restricted materials and some are provided below:

- Lead: For copper alloy conductors $\mathrm{Pb}$ is used for machinability of the conductor. Also in some cables $\mathrm{Pb}$ sheath is used to prevent ingress of moisture.

- Cadmium: Cadmium is used for wear resistance in alloy conductors. Also it is used as pigments for insulation. In addition to color, cadmium also contributes to pigment's durability against fading and resistance to heat. Cadmium compounds are used as stabilizers for PVC insulation to retard degradation due to ultraviolet light and heat.

- $\quad$ PBB \& PBDE: These are used in flame retardant jacket of cables.

- Hexavalent Chromium: Hexavalent chromium is commonly used in pigments, dyes, inks and chrome plating which are used in cable manufacturing

- Use of mercury is rare in cable industry and none the less it can come through contamination from process used in manufacturing.

From the example above it is clear that during R\&D not only individual material needs to be RoHS compliant but also process chemicals should not contaminate those materials which could end up in final product. Hence RoHS compliance testing is very important during product development cycle. Fig. 1 shows modified Nair's product development cycle and where compliance testing is required in R\&D product development instead of after pilot level production. Including compliance testing from proof of concept to prototype development provides additional benefit of improvement of industry confidence on the pre-competitive R\&D; which can then attract industrial partner with more ease.

RoHS testing is fairly easy in India with both private and government labs that are present to provide certification of RoHS compliances. Government of India laboratory at C-MET Hyderabad uses Standard Operating Procedure as per IEC 62321:2006 [13]. There are at least 29 private labs which provide RoHS related testing services all over India.

Although RoHS2 is not adopted in current form by India, but it is very likely RoHS2 would be adopted in future enactment of the E-waste Rule as has been the case of RoHS1. Since, R\&D creates products for future; one need to be couscous and a more restrictive practice of adoption of RoHS2 is advisable to avoid rejection of developed product in future.

\section{Conclusion}

A discussion on requirement of RoHS regulations in India was presented in this paper. The requirement arises from the fact that severe pollution is expected due to unscientific recycling of e-waste in India. The potential health hazards due to such pollution has been enlisted, which shows adults and children are at sever risk form such activity. Not only such pollution can cause severe health issues but could also lead to fatality. A detailed discussion of national and international scenario on RoHS, and how RoHS could be adopted in Indian $\mathrm{R} \& \mathrm{D}$ ecosystem was then discussed. Its adoption could be inserted in EE product development cycle by including compliance testing from proof of concept to prototype development stages in Nair's Product Development Cycle. Advantages of early adoption of RoHS in Indian R\&D ecosystem are avoidance of 
repetition of expected pollution from e-waste again in future, preventing health issues among researchers who handle such substances and improvement of industry confidence on the pre-competitive R\&D. Further, as a foresight, Indian R\&D ecosystem should adopt RoHS2 directly to prevent rejection of developed product in future as RoHS2 is expected to be adopted in future enactment of the E-waste Rules in India.

\section{Acknowledgements}

The authors would like to acknowledge the contribution of D. Dutta form Ministry of Electronics and Information Technology for providing the opportunity to work in this field.

\section{References}

[1] S Dutta and S Caulkin, The power of innovation, World Business (INSEAD), 2007

[2] G. H. Brundtland, Our Common Future, The World Commission on Environment and Development (Oxford University Press, 1987)

[3] S D Das, Prospects of Microwave Heating in Silicon Solar Cell Fabrication - A Review, IOSR-JEEE, Volume 6, Issue 3 (May. Jun. 2013), PP 28-38

[4] C.P.Baldé, F. Wang, R. Kuehr, J Huisman, THE GLOBAL E-WASTE MONITOR 2014, Quantities, flows and resources, United Nations University

[5] http://www.assocham.org/ [accessed $7^{\text {th }}$ July 2016]

[6] European Commission [https://ec.europa.eu/: Accessed $22^{\text {nd }}$ February 2017]

[7] Agency of Toxic Substances and Diesese Registry, Govt. of USA [https://www.atsdr.cdc.gov: Accessed 22 ${ }^{\text {nd }}$ February 2017]

[8] World health Organization, United Nations Organization [http://www.who.int/ : Accessed 22 ${ }^{\text {nd }}$ February 2017]

[9] European Food Safety Authority [www.efsa.europa.eu: Accessed 22 ${ }^{\text {nd }}$ February 2017]

[10] www.cpcb.nic.in [Accessed $22^{\text {nd }}$ February 2017]

[11] E-Waste (Management) Rules, 2016 [http://www.moef.gov.in: Accessed 22nd February 2017]

[12] http://eur-lex.europa.eu/ , [Accessed 22 ${ }^{\text {nd }}$ February 2017]

[13] http://www.rohs-cmet.in/ [Accessed $22^{\text {nd }}$ February 2017] 